Global Journal of Electronic and Communication Research.

ISSN 2249-314X Volume 12, Number 1 (2021), pp. 1-9

(C) Research India Publications

https://dx.doi.org/10.37622/GJECR/12.1.2021.1-9

\title{
Survey on Laser Guided Missile Systems and Implementation by Developing a Laser Guidance System
}

\author{
Gopisetty Srinivas \\ School of ECE, \\ REVA University \\ Bengaluru, India
}

\author{
Harshitha C Gowda \\ School of ECE \\ REVA University \\ Bengaluru, India
}

\author{
Harish Kumar Gowda B H School of \\ ECE \\ REVA University \\ Bengaluru, India
}

\author{
Jyothi ST \\ School of ECE \\ REVA University \\ Bengaluru, India
}

\author{
Ravi Shankar D \\ School of ECE \\ REVA University \\ Bengaluru, India
}

\begin{abstract}
A laser-guided missile is a projectile airborne to reach and destroy the target. The whole body is propelled to hit a predetermined target-directed through the laser beam painting towards a target. The laser is aimed to point at the goal object and its central position from the robot missile. If the target changes its initial position, the camera tracks the new position, and information is fed to an onboard computer of the missile as visual feedback, which computes a new trajectory for itself by steering its body and chasing towards the direction of
\end{abstract}


the new target and hitting it with improved accuracy. This whole system of guiding and making changes according to new information has to be updated every time instantaneously and should be made entirely automated and not controlled by any human. To design such a Stable, Accurate, and Spontaneous system lot of parameters have to be seen in Electronics and Aerodynamics. A detailed survey is made on the most available Laser Guidance System for analyzing the best way to design. This paper discusses the proposed Laser guided system developed using Raspberry-pi controller.

Keywords: Laser beam, Guidance System, Raspberry-pi Accuracy and stability.

\section{INTRODUCTION}

A guidance device consists of devices that are implemented on controlling the movement of a missile or other moving object. Every movement within the missile from the start line till it reaches the target is about and goes past the system. Here we are studying a laser-guided system for the missile. Guidance is that the process of calculating the initial and changes in its position, velocity, altitude, and rotation rates of a moving object within the air required to follow a particular trajectory [1].

A laser-guided missile could be a V-1 that strikes its target with incredible precision employing a laser for tracking its target; the target is often stationary or moving.

A guidance device consists of three sections: Input section, Processing unit, and Output section. The input section includes sensors, data, radio and satellite links, and other information sources. The processing unit integrates this data and determines the specified actions (if any) that are to be taken for achieving a correct heading. The processing unit is directly fed to the outputs which directly affects the system's performance. The output section controls velocity by interacting with devices like motors for thrust or by actuating ailerons, rudders altering directly. Components in the system include; targeting or guidance system, flight system, engine, and warhead.

During the first 1950s, the federal government did not want to be over-dependant on the German team in order that they tried to insulate themselves for military applications. One of the people who were "developed" domestically was missile guidance. MIT Instrumentation Lab, chosen by the Air Force, to produce a selfcontained system backup in San Diego for the new inter-continental missile named Atlas.

The first missile developed by Nazi Germany in war II which was used operationally was a series of missiles. The famous ones in every of these are the V-1 buzz bomb and $\mathrm{V}-2$ rocket, both of them are consisting of a mechanical autopilot keeping the missile on the wing mode along a pre-chosen route. Less well-known was a series of AntiShip and Anti-aircraft missiles, typically supported a straightforward direction system directed by the operator. However, these early systems were in-built small numbers [2]. 


\section{LITERATURE SURVEY}

The below table has a collection of information, research made across various countries and published in conferences related to Guidance System.

TABLE I. List Of Guidance Systems Published In Co

\begin{tabular}{|c|c|c|c|c|c|}
\hline & Year & $\begin{array}{l}\text { Conference Name, } \\
\text { Place \& Author }\end{array}$ & Title & Pros & cons \\
\hline 1 & 2008 & $\begin{array}{l}\text { Intl. Conf. On Control, } \\
\text { Automation, Robotics, } \\
\text { and Vision } \\
\text { Hanoi, Vietnam } \\
\text { Hla Myo Tun }\end{array}$ & $\begin{array}{l}\text { Design Analysis of } \\
\text { Phase Lead } \\
\text { Compensation for } \\
\text { Typical Laser } \\
\text { Guided Missile } \\
\text { Control System } \\
\text { Using MATLAB } \\
\text { Bode Plots }\end{array}$ & $\begin{array}{l}\text { The final lead compensator } \\
\text { network has been designed } \\
\text { to increase stability using } \\
\text { MATLAB[15] }\end{array}$ & - \\
\hline 2 & 2008 & $\begin{array}{l}\text { First Intl. conf. On } \\
\text { Intelligent networks and } \\
\text { Intelligent systems } \\
\text { Chengdu, China } \\
\text { Ke Zhang, Wei Zhang }\end{array}$ & $\begin{array}{l}\text { A Design of Data } \\
\text { fusion software } \\
\text { system for laser } \\
\text { Radar and FLIR }\end{array}$ & $\begin{array}{l}\text { The design in this article } \\
\text { collects information by } \\
\text { FLIR and achieves a new } \\
\text { method of control and } \\
\text { guide with multisensory. } \\
\text { [7] }\end{array}$ & - \\
\hline 3 & 2011 & $\begin{array}{l}\text { IE EE Shijiazhuang, } \\
\text { China } \\
\text { ZHOU Zhong-Liang }\end{array}$ & $\begin{array}{l}\text { Study on image } \\
\text { processing } \\
\text { technology in } \\
\text { imaging laser } \\
\text { detection system }\end{array}$ & $\begin{array}{l}\text { Image Processing was a } \\
\text { very effective way for } \\
\text { improving system's } \\
\text { performance[8] }\end{array}$ & - \\
\hline 4 & 2012 & $\begin{array}{l}\text { International } \\
\text { Conference on } \\
\text { Optoelectronics and } \\
\text { microelectronics } \\
\text { Changchun, China } \\
\text { Keyan Dong }\end{array}$ & $\begin{array}{l}\text { The optical system } \\
\text { design of } \\
\text { transmissive laser } \\
\text { target simulator }\end{array}$ & $\begin{array}{l}\text { As the projection system } \\
\text { design is closer to the } \\
\text { actual environment, this } \\
\text { system can simulate the } \\
\text { imaging of the far-field } \\
\text { target under near-field } \\
\text { conditions. }\end{array}$ & $\begin{array}{l}\text { Due to the size and shape } \\
\text { of the diffuse reflection } \\
\text { screen, the spot position } \\
\text { simulation is limited only } \\
\text { to a small area.[9] }\end{array}$ \\
\hline 5 & 2013 & $\begin{array}{l}\text { Journal of the } \\
\text { institution of engineers } \\
\text { India } \\
\text { Rajesh Joseph } \\
\text { Abrraham }\end{array}$ & $\begin{array}{l}\text { Application of a } \\
\text { complex lead } \\
\text { compensation for a } \\
\text { laser-guided missile }\end{array}$ & $\begin{array}{l}\text { Compensator system design } \\
\text { can be applied for efficient } \\
\text { system modeling and loop } \\
\text { shaping which gives better } \\
\text { results. }\end{array}$ & $\begin{array}{l}\text { Smaller high-frequency } \\
\text { gain of the complex lead } \\
\text { compensator tends to } \\
\text { increase the high-frequency } \\
\text { noise rejection when } \\
\text { compared to the double } \\
\text { lead compensator. [10] }\end{array}$ \\
\hline
\end{tabular}




\begin{tabular}{|c|c|c|c|c|c|}
\hline 6 & 2014 & $\begin{array}{l}\text { IEEE } \\
\text { Melbourne, Australia } \\
\text { Roberto Sabatini }\end{array}$ & $\begin{array}{l}\text { Innovative flight } \\
\text { test instrumentation } \\
\text { and techniques for } \\
\text { airborne laser } \\
\text { systems } \\
\text { performance } \\
\text { analysis }\end{array}$ & $\begin{array}{l}\text { The software tool used for } \\
\text { 3D simulation is available } \\
\text { for both training mission } \\
\text { planning and post-mission } \\
\text { data analysis. }\end{array}$ & $\begin{array}{l}\text { The exact nature of the } \\
\text { correlation between the } \\
\text { various SPD has not been } \\
\text { identified. [11] }\end{array}$ \\
\hline 7 & 2017 & $\begin{array}{l}\text { IEEE } \\
\text { Gurgaon, India } \\
\text { Hemani Kaushal }\end{array}$ & $\begin{array}{l}\text { Applications of } \\
\text { laser for tactical } \\
\text { Military operations. }\end{array}$ & $\begin{array}{l}\text { This weapon when used as } \\
\text { range finders, LIDARs, } \\
\text { target designators, they } \\
\text { serve as a powerful tool to } \\
\text { the war-fighters. }\end{array}$ & $\begin{array}{l}\text { As this is a directed high- } \\
\text { energy weapon, it requires a } \\
\text { sufficient amount of power. } \\
\text { Also, during unstable } \\
\text { weather conditions, these } \\
\text { weapons can deflect and } \\
\text { can miss the target. [12] }\end{array}$ \\
\hline 8 & 2019 & $\begin{array}{l}\text { Journal of systems } \\
\text { engineering and } \\
\text { electronics } \\
\text { China } \\
\text { ZHANG Jiandong, } \\
\text { SHI Gouging }\end{array}$ & $\begin{array}{l}\text { A Quantitative } \\
\text { Method for } \\
\text { calculating } \\
\text { irradiation area of } \\
\text { target designator }\end{array}$ & $\begin{array}{l}\text { Based on the laser } \\
\text { transmission model and the } \\
\text { motion model, an algorithm } \\
\text { was made for measurably } \\
\text { calculating the irradiation } \\
\text { area of the laser target. }\end{array}$ & $\begin{array}{l}\text { After comparing the } \\
\text { simulation results of } \\
\text { different irradiation fields, } \\
\text { it was seen that the shape of } \\
\text { the reflection surface } \\
\text { greatly affected the size and } \\
\text { shape of the irradiation } \\
\text { field. [13] }\end{array}$ \\
\hline 9 & 2020 & $\begin{array}{l}\text { IEEE } \\
\text { China } \\
\text { QIJIA YUN, YANG } \\
\text { PEI }\end{array}$ & $\begin{array}{l}\text { Modeling the } \\
\text { impact of high } \\
\text { energy laser weapon } \\
\text { on the mission } \\
\text { effectiveness }\end{array}$ & $\begin{array}{l}\text { Between the mission } \\
\text { effectiveness and the } \\
\text { subsystem design } \\
\text { parameters, an SoS view of } \\
\text { the relationship is } \\
\text { established through a } \\
\text { mission scenario. }\end{array}$ & $\begin{array}{l}\text { As the power supply is } \\
\text { limited it might lead to } \\
\text { insufficient battery } \\
\text { capacity, which leads to } \\
\text { system shutdown in the } \\
\text { middle of the engagement } \\
\text { during flight. [14] }\end{array}$ \\
\hline
\end{tabular}

\section{RELATED WORK}

1) In 2008, Hla Myo Tun, et al explained the lead compensator, designed to increase stability using MATLAB[15]

2) In 2008 , Ke Zhang, et al

3) In 2011, ZHOU Zhong Liang, et al

4) In 2012, Keyan Dong, et al

5) In 2013, Rajesh Joseph Abrraham, et al 
6) In 2014, Roberto Sabatini, et al

7) In 2017, Hemani Kaushal, et al

8) In 2019, ZHANG Jiandong, SHI Gouging, et al

9) In 2020, QIJIA YUN, YANG PEI, et al

\section{IV.METHODOLOGY}

The RaspberryPi 3 model $\mathrm{B}+$ is taken as an onboard computer that runs OpenCV package for image/video analisis, which in turn is fed by a camera, then the computed data is sent to PCA9685 through GPIO pins on the RaspberryPi which helps in giving control over the servos. The servos which are connected to the control surface help with steering in 3D. For producing thrust BLDC motor is connected to its Electronic Speed Controller (ESC) which takes command from Raspberry Pi and produces Constant thrust.

A. Block diagram.

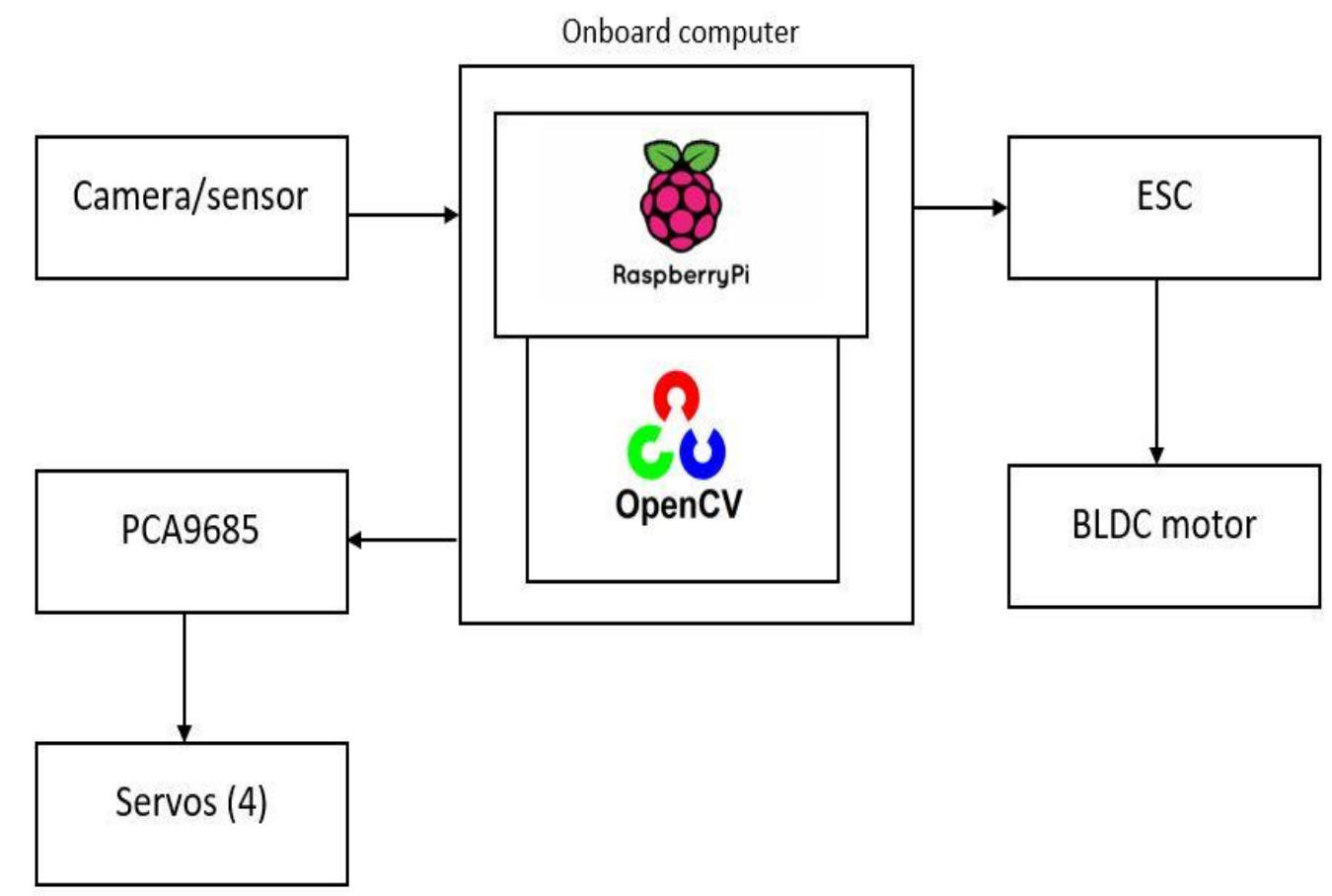

Fig.1: Block diagram of the connection of components to the missile 
B. Hardware and software requirements.

- Hardware Used

Table 1: Hardware components used

\begin{tabular}{|l|l|l|l|}
\hline S.N & $\begin{array}{l}\text { Hardware } \\
\text { Components }\end{array}$ & Specification & Description \\
\hline 1 & Rpi Camera & 5 mega-pixel & $\begin{array}{l}\text { Acts as a sensor and video feed } \\
\text { to Rpi. }\end{array}$ \\
\hline 2 & $\begin{array}{l}\text { Raspberry pi } 3 \\
\text { Model B+ }\end{array}$ & $\begin{array}{l}\text { Broadcom BCM2837B0 } \\
64 G b \text { ROM } \\
1 \text { GB SDRAM }\end{array}$ & $\begin{array}{l}\text { The video feed is processed in } \\
\text { OpenCV and the output is given } \\
\text { to the servos through PCA9685. }\end{array}$ \\
\hline 3 & $\begin{array}{l}\text { Adafruit } \\
\text { PCA9685 servo } \\
\text { driver }\end{array}$ & $\begin{array}{l}\text { 16-channel 5v operation } \\
\text { voltage 25MHz internal } \\
\text { oscillator }\end{array}$ & $\begin{array}{l}\text { Gives a servo-independent power } \\
\text { supply and a smoother PWM } \\
\text { signal. }\end{array}$ \\
\hline 4 & $\begin{array}{l}\text { Servo motors } \\
\text { SG90 model 180-degree } \\
\text { freedom of motion }\end{array}$ & $\begin{array}{l}\text { Control the 'control surfaces' to } \\
\text { maneuver in 3D. }\end{array}$ \\
\hline 5 & $\begin{array}{l}\text { ESC (Electronic } \\
\text { speed } \\
\text { controller) }\end{array}$ & $\begin{array}{l}16.3 \mathrm{~g} \\
7-26 \mathrm{~V} \text { and 30A max }\end{array}$ & $\begin{array}{l}\text { Control's the speed of the BLDC } \\
\text { motor. }\end{array}$ \\
\hline 6 & BLDC motor & $2200 \mathrm{KV}$ & Used for producing thrust. \\
\hline 7 & Li-po battery & 3 cell 11.1V & On-board power source. \\
\hline
\end{tabular}

\section{Software Used.}

\section{Thonny IDE(python 3.7)}

Thonny is an Integrated Development Environment (IDE) for python which is designed and developed for beginners. Thonny IDE supports for C-Python and MicroPython. This program works on Windows, Linux, and macOS. It is available as a binary bundle that includes a pip-installable package or python interpreter. This software is used for explaining Variables and memory by using a simplified model (name $\rightarrow$ value) or by using a more realistic model (name $\rightarrow$ id $\rightarrow$ value). It can be installed using the operating system package manager on Raspberry Pi, Ubuntu, and Fedora.

\section{FUTURE RESEARCH DIRECTIONS}

A large and sufficient amount of power, most preferred in watts, is required for the design and testing of high laser weapons. These high-power transmissions cause serious challenges during field testing. Therefore, the performance of these systems has to be estimated under a controlled environment. Many experiments have come up 
as a very important challenge because the third domain is now gaining development, maturity, and configuration safe, comprehensive, and cost-effective for high experiments.

Also, high-energy laser generation systems require efficient cooling mechanisms which have the capability for maintaining stable temperatures during transmission cycles.

The most important consideration when handling high-power laser transmission is minimizing fatal accident and threats to friendly sensors and equipment which is nearby.

\section{RESULT}

The laser colour is detected and tracked by the onboard computer and guides the missile towards the target on which the laser is painted. Fig-3 shows the identification and tracking of red colour lasered target as an example. This missile has the capability of striking the designated target accurately $50 \%$ of the time.

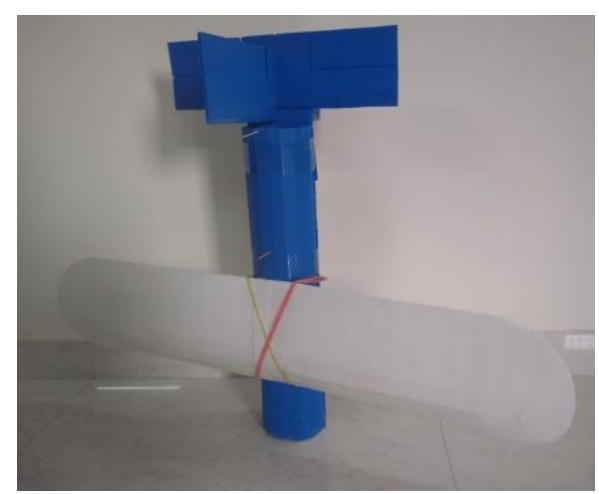

Fig 2: Missile body

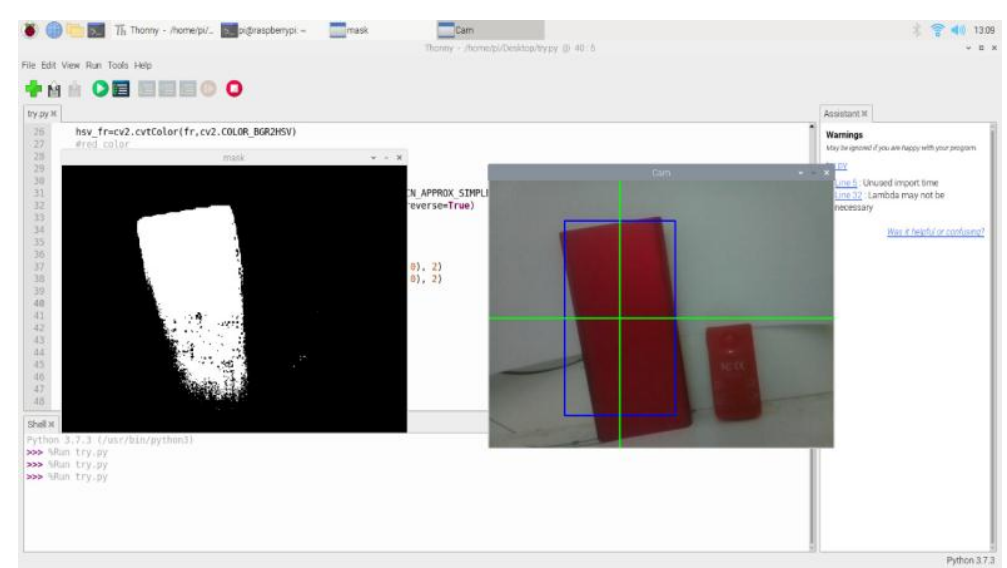

Fig-3: Output of program identifying the target. 


\section{CONCLUSION}

Laser technology has shown a strong ability to transform modern-day battlefield structure, through supportive defensive and offensive applications. The lasers also serve as a powerful device for the soldier or battler when they are employed as targetdesignators, range-finders, LIDARs, and secure communication systems. Laser technology has made amazing progress over the past decades. This paper reviews the laser applications and projects related to strategic defence actions both on the land surface and in space. It has also covered an extensive overview of diverse laser-based projects of the last decade.

\section{REFERENCES}

[1] https://en.wikipedia.org/wiki/Guidance_system

[2] https://en.wikipedia.org/wiki/Missile_guidance

[3] https://www.scienceabc.com/innovation/how-guided-missiles-work-guidancecontrol-system-line-of-sight-pursuit-navigation.html

[4] http://www.madehow.com/Volume-1/Laser-Guided-Missile.html

[5] https://patents.google.com/patent/US3995792A/en

[6] https://www.historylearningsite.co.uk/world-war-two/world-war-two-inwestern-europe/the-v-revenge-weapons/the-v-weapons/

[7] H. J. W. Z. Z. T. Ke Zhang, et al "A Design of Data Fusion Software System for Laser Radar and FLIR," First International Conference on Intelligent Networks and Intelligent System, 2008.

[8] Y. J. ZHOU, et al "Study on Image Processing Technology in Imaging laser detection system" IEEE, 2011.

[9] K. Dong, et al "The optical system design of transmissive laser target simulator," International Conference on Optoelectronics and Microelectronics, 2012.

[10] R. J. Abraham, et al "Application of a complex lead compensation for a laser-guided missile," Journal of the institution of engineers, 2013.

[11] R. Sabatini, et al "Innovative Flight Test Instrumentation and techniques for airborne laser systems performance analysis" IEEE, 2014.

[12] H. Kaushal, et al "Applications of Lasers for Tactical military operations" IEEE, 2017.

[13] S. G. ZHANG Jiandong, et al "A quantitative method for calculating irradiation area of target designator," Journal of Systems Engineering and Electronics, 2019. 
[14] Y. P. QIJIA YUN, et al "Modelling the impact of high energy laser weapon on the mission effectiveness" IEEE, 2020.

[16] "Lawrence Berkeley National Laboratory, "Electromagnetic Spectrum" U.S.Department of Energy National Laboratory, University of California.

[17] Whitwam Ryan, et al "International Space Station may get laser cannon to vaporizeorbital debris", Extreme Tech 2015"

[18] Perakis N, et al "Project Dragonfly: a study of interstellar travel using laser-powered light sail propulsion" 
